\title{
Ghana muntie: from Station ZOY to the Ghana Broadcasting Corporation
}

\author{
Bernard Senedzi (B. S.) Gadzekpo
}

The excerpts below are from two of the sixteen chapters in B. S. Gadzekpo's radio memoir. In 'Battles at the microphone', Gadzekpo describes the diverse ways in which he and other Vernacular Announcers made their mark on wartime programming during World War Two, including how they carefully selected what could be aired as news and rallied local support for the war effort. The chapter 'The music talent hunt' details his tireless efforts at identifying and recording indigenous music to play on air in order to keep local audiences glued to the radio, especially after the war. The full text of the manuscript is available with the supplementary material published with Audrey Gadzekpo's article introducing this work at <https:/ldoi.org/10.1017/S0001972021000012>.

\section{Chapter 5: Battles at the microphone}

$\mathrm{We}^{1}$ made our work as light and as cheerful as possible with jokes of all kinds when there was nothing pressing to be done. We regarded one another as equals among whom there was keen competition, and each did his best to satisfy his listeners. Although there was to be no promotion for us in the Information Department, we worked conscientiously to the satisfaction of our bosses. We were aware that promotion, if there was to be any at all, must be made by or through the Educational Units from which we came. Our secondment to the Information Department did not automatically qualify us for any preferential treatment over our fellow teachers in the classroom.

When the Information Officer was otherwise engaged and could not be with us for the usual discussion and the necessary briefing for the day, we would appoint a 'primus inter pares' among us to lead the discussion. We did this in turn. The following is one of such a morning, and one of the Hausas, Mallam Belo, was in the chair.

(It's 8:30am the Announcers start to come in. They exchange greetings.)

Belo: $\quad$ Good morning, gentlemen.

All: $\quad$ Good morning, Mallam.

Belo: Have the news item been marked to show which we should broadcast?

Gadzekpo: $\quad$ Not yet. You, the chairman for this morning will have to do that. There is a press conference going on now at our Head Office and the Information Officer or his assistant cannot be with us this morning.

\footnotetext{
${ }^{1}$ By 'we' he meant Vernacular Announcers. Belo and Issa were responsible for Hausa language programmes, Ankrah and Bruce-Tagoe for Ga, Gadzekpo for Eve, Yeboah and Frimpong for Twi, and Quansah for Fanti.

(C) The Author(s), 2021. Published by Cambridge University Press
} 
Belo: $\quad$ All right, let's go through quickly. I suggest we delete item 3; tick item 4 which I suggest should be done by only the Fantis and the Ewes, as it will be of interest to them as fishermen. ${ }^{2}$

Ankrah: I think it's an important item. I suggest we all do it.

Gadzekpo: This news happened some time ago, when I was teaching at Keta; ${ }^{3}$ I can tell you the full story, as I heard it.

Yeboah: Let's hear it then.

Bruce-Tagoe: Come out with it.

Frimpong: Were you present at the incident?

Gadzekpo: $\quad$ Some Fanti fishermen went to fish in the sea at Keta. They were far away from the shore; when they were on their way back to the shore, a German submarine surfaced near them. The bearded crew brandished their swords saying 'you people sing Britannia rules the waves! Britannia rules the waves! Where are the British now? We Germans now command the seas.' When the terrified fishermen started to row away, the Germans shelled the fishing boat and it was badly damaged. Some of the fishermen were also injured.

Yeboah: $\quad$ So you mean to say that the Germans came all the way to Keta? Gadzekpo: This was what the fishermen said and I am giving it to you only as background. I suggest we all follow strictly the text of the news item, without adding or leaving anything.

Quansah: I think I read something like that in the 'Empire at War'. ${ }^{4}$

Frimpong: $\quad$ Yes, it is true, I also read it.

Belo: $\quad$ But what about the item dealing with monkeys on the Ningo ${ }^{5}$ Road?

Issa: $\quad$ Monkeys also in the news [laughter].

Ankrah: Mallam, on with the next item, and leave the monkeys alone; we are wasting time.

Belo: $\quad[$ Reads on] ... the enemies were attempting to ...

Issa: $\quad$ Please read that again. Did you say attempting? I heard 'speeding up'.

Quansah: I I heard 'attempting', I bet my life, I heard 'attempting'.

Belo: $\quad$ Quansah, you have only one life, what will become of you if you have been proven wrong? What will happen to your life?

Bruce-Tagoe: Then of course, we shall announce: 'The death is reported of Mr. Quansah, Fanti announcer who died on active service fighting in the home front. There will be a wake-keeping in the Town Hall where the body will be laid in state tomorrow' [laughter].

\footnotetext{
${ }^{2}$ Fanti-/Fante-speaking people are mainly found in the central coastal region of Ghana while the Eve live mostly along the coast in south-eastern Ghana, southern Togo and parts of southwestern Benin. Fishing was traditionally the predominant occupation of both these ethnic groups.

${ }^{3} \mathrm{~A}$ coastal town in the Volta Region.

${ }^{4} \mathrm{~A}$ weekly war propaganda printed broadsheet supplied from London by the Ministry of Information.

${ }^{5} \mathrm{~A}$ fishing and farming community in the Greater Accra Region of Ghana.
} 
Yeboah: $\quad$ Mallam, carry on, we are wasting time. Anyway, that death will not occur in our time, here.

Belo: $\quad$ Did anybody hear anything else?

Gadzekpo: $\quad$ In fact I heard both 'attempting' and 'speeding up'; 'attempting' came at 9 o'clock last night, whilst 'speeding up' came this morning at 6 o'clock; either will do for our broadcast, we have only to decide which to take. But I suggest, in order to clear all doubt, we check up on the BBC news broadcast at 9 o'clock; it is almost 9 .

Local news items dealt specifically with the war effort, and in this, we the Announcers were proud that we fought out battles at the microphones. We kept on encouraging the farmers to grow sufficient food, as imported food was no longer available due to the war. We did succeed in this, for there was no serious food shortage in the country during the war.

It was only after the war that the general effects of scarcity of goods, resulting in inflation was felt. Raw materials such as bauxite and palm kernel were in demand during the war, and it was our duty to stress their importance in the manufacture of ammunition to strengthen their production.

Our announcements encouraged people in the big towns to contribute to the Spitfires Fund, ${ }^{6}$ which was ably organized by Mr. F. A. B. Johnson, Spitfirehene, ${ }^{7}$ who did not live long to see the effect of the Spitfires on the enemy. Through his enthusiasm, concerts, dances and other activities were organized to raise funds to purchase the aircraft. This is an extract from what he wrote in the 'Empire at War' No. 43 of 19th July 1940:

While our troops arrive on the battle front, the home front is doing its duty no less eagerly. The double effort required by our Spitfires Fund and War Charities Fund has far from exhausted our resources. To the War Charities Fund generous subscriptions continue to come in. Two firms and their employees have recently sent cheques for over $£ 800$. Pensioners continue to write in, asking that generous monthly sums be deducted from their pensions for war charities. Last week the Accra War Charities Committee, having already made generous remittances, gave $£ 1,100$ to those brave civilians who were disabled or to the dependants of those who were killed when they took part with their small boats in rescuing our troops from the hell at Dunkerque Beach ${ }^{8} .$. The work of mercy goes on but remembering Cromwell's famous 'Out all you can', people of every work in life are giving to the Spitfires Fund. Some boys and girls of Effiduase Methodist School near Koforidua ${ }^{9}$ sent $£ 1.1$ s.6d. with a letter saying 'we have some responsibility in the present war, but we are so young to hold a gun and fight, and we think our pennies collected can help in buying the Spitfires!'

\footnotetext{
${ }^{6} \mathrm{~A}$ fundraising campaign aimed at mobilizing money to support the UK's acquisition of Supermarine Spitfire aeroplanes during World War Two. Spitfire funds were established in the UK and other countries, including colonies such as Ghana (then the Gold Coast), where events were organized and donations solicited from ordinary people for the fund.

${ }^{7} \mathrm{~A}$ local coinage meaning Spitfire chief. Ohene means chief in Twi.

${ }^{8}$ This is a reference to the evacuation during World War Two of British and other Allied soldiers from the harbour of Dunkerque/Dunkirk in northern France in May-June 1940.

${ }^{9} \mathrm{~A}$ town in the Eastern Region of Ghana.
} 
To keep the morale of the soldiers in the battlefields, messages were recorded by their wives and relatives. These were flown and played to them. The soldiers also recorded messages which were played from Station ZOY to their wives and relatives. When such recordings were received, it was our duty to play them and make sure that the language of the message was suitable for broadcasting and that the quality of the recordings on soft disc was good. Advance notice over the radio was also given to those for whom the messages were intended, to listen on the day of broadcasting.

On one occasion, one of us, without first listening to the message, assumed that the recording was a good one and so put it on the air. After the record had played for about a minute telephone calls from several parts of Accra were received at Broadcasting House complaining of the indecent language the message contained. The offender was accordingly disciplined.

Sometimes, upon request, we gave our individual opinion in writing. This was particularly so in the case of newspaper articles on which the Information Officer wanted to have our individual comments. An article titled 'Infiltrative Propaganda' appeared in a British paper. Among other things the writer referred to the failure of propaganda in the medical field in Africa, and each of the ten of us (Announcers) was asked to give his individual comment in writing. Below is part of one of such comments:

Propaganda is a total failure when the African is not first made to know the reason for doing a certain thing before he is asked to do it. The African, and the Gold Coast African for that matter, is a strong believer in quick results, and since European medical treatment is a slow process, it is no wonder that propaganda in the Medical field should fail in Africa. To [the] majority of illiterates and some literates disease and sickness owe their origin to evil persons, usually enemies, and they are unconvinced that diseases are caused by any other factor. They even believe that an evil person has power over European medicine, and therefore when some of them are receiving European medical treatment, they find it necessary to appease the evil ones by offering sacrifices to enable them [to] loosen their power over the European medical treatment.

In the greater part of the Gold Coast the inspection of houses for larvae and filth is not yielding the desired results. The reason is that Sanitary Inspectors who carry out the inspection, instead of acting as instructors and advisers giving practical examples showing the evil in harbouring larvae and filth in houses, only act as bullies. When a person has understood the reason for doing something, he does not need to be punished before he does it. No amount of punishment can stop the larvae from breeding in the pots and pools if the reasons for their breeding are not understood by those in whose pots they are found.

A successful propaganda largely depends upon the approach. Once the propagandist has failed at the outset to convince his audience, it would be hard for him to convince them afterwards. For this reason the propagandist should direct his propaganda at the flank, as suspicion may surround propaganda by frontal attack.

After a censorship of films which we attended at the Rex Cinema from time to time as part of our duty, we also had to give our opinion. Some people would enjoy seeing films for which they did not have to pay anything. But ours was not so. Having been occupied the whole day we usually felt tired and liked to go home immediately after broadcasting, to rest. 
We therefore grumbled each time there was a censorship of films to attend. On one such occasion we saw to our shame a film on nudity in Mamprusi. ${ }^{10}$ On the following morning, the Information Officer or his representative as usual, called at the office for our reaction. The discussion which followed was rather bitter, to the disappointment of the Information Officer. Among other things, we said bluntly that such a film was not a subject about which the British should be proud. If British rule for such a long time could not eradicate nudity in the country then it would only mean that they, the British, were not interested in the progress of the people. They were only interested in exploiting the country and not in the improvement of the standard of living of its people. The Information Officer argued that it was the custom of the Mamprusi people to be nude and that it was not the policy of the Government to interfere with the custom of the people. We disagreed with this explanation arguing that in the Gold Coast it was the result of poverty and lack of civilization. We tried to convince him that it was possible for the enemy to use the nudity of Mamprusi people against them that they the British brought no civilization to the country as a whole and that they, the enemies would do better if the country belonged to them. Whether the Information Officer was convinced or not, he appeared to agree with us that nudity in any part of the country was nothing to be proud of.

Our collection of reactions was not confined to censorship of films alone. It extended to the radio also. In a class of 40 pupils under a teacher's care, he is able to see from the very look on their faces whether the lesson is understood or not. But a broadcaster talking to the whole world is not able to find out at once the impact of his broadcast on his listeners. The best he can do is to make contact with some of his listeners afterwards and ask them what they thought of his particular broadcasts.

For this reason, treks were arranged periodically to enable contact with some of the listeners. Many listeners were pleased to see us for the first time. Before then, they used to have quite a different impression of each of the Announcers. On seeing us for the first time they expressed surprise when the look of a particular Announcer was different from what they had expected. Some of them would say: 'From your voice on the air we thought you were a stout fellow, it never occurred to us that you were so thin.'

Others on seeing us for the first time would burst into laughter, remembering some broadcast which had amused them some time ago, but which we had forgotten ourselves.

On such occasions we discussed with the listeners at the Information Bureau what programmes they enjoyed listening to, and those they did not like. We also answered questions the listeners asked. Those were the formative years of listening habit and no serious criticism of broadcast was expected from the listeners. Besides, in the colonial days, many did not like to interfere with anything done by the Government and so they did not criticize [the] Government's actions.

It was generally true that listeners kept silent over anything which pleased them but their reactions to anything they did not like reached the Information

\footnotetext{
${ }^{10}$ A town in the Northern Region of Ghana. Mamprusi people are also found in Togo.
} 
Department indirectly or through anonymous letters, but face to face with the announcers, they could only say all the broadcasts they heard were good.

The broadcast which they enjoyed most, and which they did not hesitate to comment on, was music - indigenous music. In this case, it was not necessarily the music that pleased them, but the fact that the words of the music played were in their particular language. In the early stages, listeners were not sure whether music came from gramophone records or from live broadcasts. This they always wished to know when they met us.

Teachers were however outspoken in their criticism when we called on them at their schools. Where they did not believe us they never hesitated to say so. Their criticisms were fair and constructive. They were definitely better informed about the war than most of those who visited the Information Bureaux which were opened during the war to give factual information.

An incident occurred at Keta which proved the veracity of our news broadcasts. In a report after a trek to the Trans Volta Togoland (now the Volta Region), I had written: 'In one of our treks to the TVT Region we arrived at Keta when the news broadcast was about to start. At each station we arrived at, my partner Kobla Senayah in Accra who had a copy of our itinerary, sent us special greetings at news broadcast time. On that particular day there was to be an eclipse of the moon during the Ewe news broadcast time. Before starting the news, he sent special greetings to us (Mr. T. J. Lennard and me) and to the listeners, telling them that we had come to find out what they thought of our broadcasts, and he hoped they would co-operate with us in speaking their minds. Then he started the news and at the end, he said if they, the listeners, would look westward after his broadcast, they would realize that "the sun has caught the moon" according to local parlance, meaning there was an eclipse. At once, all eyes, including mine, turned westward. The sun did catch the moon; there was the eclipse indeed.

'There followed a loud applause and praises to the Announcers, who they said, always broadcast nothing but the truth. From that day the veracity of our news broadcast was established. Soon, whenever someone was in doubt and wanted assurance that what he was being told was true, it became a saying at Keta: "Did you hear it from the Radio."”

Another trek we the Announcers undertook worthy of mention was to the West African Cocoa Research Institute (WACRI) at Tafo. This was undertaken to acquaint ourselves with the ravages of the Swollen Shoot Disease which was killing cocoa trees in the country and what was being done at the Institute to control it. Such treks were really useful as they gave us practical knowledge of the problems involved. These naturally improved our broadcasts on the subject, for they gave the necessary background which made our broadcasts authentic. We were taken round cocoa farms infected with the disease and were shown affected trees which were compared with non-affected ones. Other cocoa diseases were also shown to us on the farms. We were shown where trees were being cut down and new areas being re-planted with new species of cocoa seedlings. We learnt that there were over 100 species of cocoa.

Collection of reactions was not confined to local broadcast alone; it went farther afield to the General Overseas Service of the British Broadcasting Corporation. During our discussion in the morning, the Information Officer or his representative would ask what we thought about certain programmes 
broadcast the previous evening, especially to West Africa. Some of these broadcasts went under the general title 'Calling West Africa' which comprised special talks, discussions or music which would interest the West African. In the talks on 'Experiment in Freedom' there were suggestions as to how to prepare the then British African Colonies for independence. Here also we gave our reactions bluntly. We told our bosses that it was one thing telling someone what to do, and another, how to help the person to do what he ought to do.

Other broadcasts on the General Overseas Service were not enjoyed by many in West Africa. They were broadcast on shortwave, which the majority of African listeners did not have. One of the popular entertainment programmes during the war was 'Tommy Handley in Itma', 'Itma' being short for 'It's that man again.' West African listeners, without the necessary background, enjoyed part of it but the jokes at which other listeners laughed had no effect on them.

\section{Chapter 8: Music talent hunt}

I was put in charge of music generally, but entrusted with the particular duty of musical talent hunting all over the country. My colleague was put in charge of all speech programmes such as talks and features. By virtue of my post as Programme Officer in charge of music I could trek to any part of the country to look for suitable music to record on soft discs, there being no tape recording facilities in the country at the time. I usually rehearsed the choirs or bands in advance and when I was satisfied with their performances, the recording van was sent to meet me at the venue for recording.

My most fruitful areas of discovery were in Peki, Kpandu and Amedzofe ${ }^{11}$ for Ewe music. Hausa and Dagbani music took me to Kumasi ${ }^{12}$ and Tamale. ${ }^{13}$

In Eweland, there was music galore but like the desert flower 'born to blush unseen', the music of Eweland wasted its sweetness upon the mountain air, ${ }^{14}$ as it was not made available to the outside world. The music was generally choral, but it was choral music with a difference - neither western nor indigenous. The musicians steered a middle course in their composition which for lack of a better term we can refer to as African Church music. The pioneer in this field is Dr. Ephraim Amu ${ }^{15}$ followed by others like Dr. Otto Boateng and Emmanuel Agor, both students of Dr. Amu, and also Frank Nyaku. We started recording this type of music for broadcast purposes as early as 1951 but how much of it remains today? It is regretted that the soft recordings have deteriorated in quality as they were not processed or reproduced on more lasting discs.

In the initial stages of our recordings for the radio, because of its novelty, some choirs and singing bands travelled uninvited to meet us in villages where we camped. There was little or no payment for such bands whose music we recorded without prior rehearsal; but payment or no payment, they were willing to perform.

\footnotetext{
${ }^{11}$ Eve-speaking towns in the Volta Region of Ghana.

${ }^{12}$ Ghana's second city and the home of the Ashanti king.

${ }^{13}$ The capital town of the Northern Region of Ghana.

${ }^{14}$ This appears to be a co-optation of Thomas Gray's 'Elegy written in a country churchyard'.

${ }^{15} \mathrm{~A}$ renowned ethnomusicologist and composer from Peki.
} 
With increased fees for good performance some of the music group quickly disintegrated. Often this was brought about by the disparity in sharing the recording fee. The choir or band leader would claim that the group was formed by him; the instruments belonged to him; and he paid for the transport which brought them to the recording venue, and therefore he was entitled to the lion's share. Dissatisfaction then crept in among the members of the choir or band and the next practice left only the leader and a few loyal followers.

Church choirs or singing bands in the urban areas, like all human activities, can never be permanent; they are often disrupted by transfers of their members. The only choir which has kept its high standard of performance and does not seem to have been greatly disrupted by the movement of its members is the DAMAS Choir in Accra. This all-purpose choir, whose name is made up of [the] initial letters of the names of the four foundation members, is as lively today as it was over 25 years ago. The names of the four foundation members are Duodu, Attoh, Mallet and Amartey. They first started as a benevolent society, but then Ishmael Adams ${ }^{16}$ joined them two years later in 1945, when they became a choir. The choir has a varied repertoire - sacred and secular - replenished from time to time with modern numbers.

I do not intend to make a list of all choirs or bands which contributed to the music programmes on Station ZOY, but mention must be made of Adwonto Kuw, a Fante singing group which enlivened the Fante musical programmes in the fifties. Unlike the DAMAS Choir, little is heard of them these days. But for a few of their recordings still available they would have been unheard of today. This singing group was originally led by Mr. Entsua-Mensah, who composed most of their songs and who later handed over to Mr. Fred Therson-Cofie. Now that facilities exist for commercial recordings, it is high time we preserved albums of records by composers.

Trekking for mobile recording in the early days of broadcasting was difficult. The roads were bad. Those which were usable were bumpy, dusty or overgrown with weeds. Others had narrow and dangerous wooden bridges over which only the courageous could drive. A trekker in those days was lucky when the car did not fail him on a disused road and had to be towed a long distance for repairs. On rainy days the roads were muddy and slippery and cars with worn-out tyres easily skidded and landed in ditches.

Rest houses were often not available for occupation or they were so remote from the town that it was only those who had the courage to live isolated lives [who] cared to occupy them. Sometimes application for the use of a rest house, made far in advance to the head office, was not communicated to the caretaker in the village where it was situated. When this happened, nothing could move the usually strict caretaker to open the doors, unless he heard from the District Commissioner or his clerk. On account of the inconveniences connected with rest houses and the difficulties we met in booking them, we always put up with teacher-friends in Mission School grounds. In the absence of a friend or an

\footnotetext{
${ }^{16}$ Adams became leader of the group, which became very prominent. In 1970, DAMAS Choir was one of a select group of local acts to perform at the fourteen-hour 'Soul to Soul' music concert featuring African-American singers and bands such as Wilson Pickett, Ike and Tina Turner, and Santana.
} 
acquaintance, we were satisfied with putting up in a classroom made available to us by the headmaster or the station pastor. We would fix our camp beds in the classroom and pack off early, before the morning session began. On such a recording trip, it was easy to be committed to record some musical items below standard provided by a hospitable choirmaster. In order to avoid this sort of embarrassment, I always made sure that the recording team did not seek hospitality from any of those to be recorded. My recording team consisted of a technician Mr. C. L. Tetteh or Mr. A. K. Ablordepey - the driver of the recording van and my assistant, usually a Programme Assistant.

The treks became interesting only when one unexpectedly met an old friend or colleague one has not seen for many years. On such rare occasions the conversation was about the good old days and about the teachers who helped to shape our destiny. It was a joy when, after experiencing the inconveniences of trekking, one returned to Accra with a good harvest of new recordings.

Other treks occasionally took me to Ashanti, North and other regions, but the distance between towns and villages in the north scared me. I was greatly relieved when our areas of activity were re-divided between us to enable my colleague to be responsible for both music and speech programmes in Akan. This meant that he could travel all over the country, especially in Akanland, to record music and other programmes.

New programmes on the air and new songs here and there brought a sharp noticeable improvement in our broadcasts, and many did not like to miss listening to certain programmes. We built most of the programmes ourselves. It was our job to write and produce some of the programmes, especially plays and features as there were no radio script writers and artistes known to us at the time. However, as time went on, script writers became available.

One of the most successful productions which Ewe listeners never tired of was an adaptation I did of the 15th century morality play 'Everyman'. The human element in the story could suit any language. The inspiration to produce it in Ewe came to me when I was privileged to produce it in English after the play was staged at the Community Centre, Accra, by the students of the University College, ${ }^{17}$ then housed at Achimota. We repeated it several times, but the listeners asked for more repeats. It is however unfortunate that though the script as broadcast exists, no recording of the programmes was preserved to show the high standard of production Radio Ghana attained from the early days.

Radio indeed is one of the most effective means of mass communication. This is proved by the fact that some of the broadcasts we did years ago still ring in the ears of some of those who heard them. It was therefore no surprise to me when, one day, some old listeners of mine, on seeing me, started to laugh heartily, when they remembered one of the amusing talks I had given some time ago. In those early days, one man did everything that came his way. We were in our own way journalists, playwrights, producers at one time, and artistes at another. The English title of the talk, a light-hearted one I gave in Ewe, was titled 'Pretending to be young'. Though it was broadcast about 25 years ago, it is interesting today as it was at the time.

Here it is briefly:

\footnotetext{
${ }^{17}$ Now the University of Ghana.
} 
Two old men boarded a bus. From their looks one appeared much older than the other. The older of the two had dyed his hair and thus pretended to be the younger. All the seats on the bus were occupied when they got on. It appeared to be a peak period and people were rushing to or returning from their places of work.

Respect for age made a school boy on the bus rise up instantly to offer his seat to the man who had not dyed his hair but kept it naturally grey, thus appearing that he was much older than his friend. There was no other offer of a seat to the blackhaired man who was pretending to be young, and he had to stand up all through the drive.

As ill-luck would have it, a little boy suddenly crossed the road and the experienced bus driver, in his attempt to save the life of the boy, suddenly applied the brakes. You can imagine what followed. The pretender or the older man whose wrinkled face did not match his dark hair, found himself on the floor of the bus. His fall caused laughter rather than sympathy for him. His colleague rose up smartly from his seat to lift him up, saying, 'it does not pay to pretend to be young'. From that day up to now some of my listeners who were amused by the talk still address me by the title of the talk 'Pretending to be young', when they see me. 